\title{
Cut-And-Paste Justice: A Case Comment on \\ COJOCARU V. BRITISH COLUMBIA \\ WOMEN'S HOSPITAL AND HEALTH CENTRE
}

\author{
ALAIN ROUSSY*
}

\section{INTRODUCTION}

The Cojocaru v. British Columbia Women's Hospital and Health Centre decision, ${ }^{1}$ released by the Supreme Court of Canada on 24 May 2013, is one of those cases that starts off being about one thing, but ends up being about quite another. Indeed, the initial case is one of allegations of medical negligence against a number of doctors and nurses regarding a baby boy who suffered brain damage at birth. It is not, however, for this tragic event that this case will be remembered in Canadian jurisprudence. Rather, it is primarily the manner in which the trial judge opted to draft his reasons that made this case find its way to the country's top court. Indeed, the reasons of the trial judge were copied extensively from the submissions of the plaintiffs. ${ }^{2}$ For this reason alone, the majority of the Court of Appeal for British Columbia ordered a new trial. ${ }^{3}$ The Supreme Court, dealing with the issue of copied reasons for the first time, disagreed. It found that "judicial copying” may not be something to be encouraged, but is nonetheless generally fine. It is only when "the incorporation of the material of others would lead a reasonable person apprised of all the relevant facts to conclude that the trial judge has not put his or her mind to the issues and made an independent decision based on the evidence and the law"4 that the decision can be set aside. This case comment will review the Cojocaru decision and the Court's analysis, discuss what are the perceived shortcomings of the decision, consider the main takeaways for various parties, and examine a surprising comment contained in the decision.

\section{The FACTS AND TRIAL DECISION}

Shortly before immigrating to Canada from Romania in 2000, Monica Cojocaru learned that she was pregnant. She already had one son who had been delivered by caesarean section in Romania. Upon arriving in Vancouver, she was referred to Dr. Yue, an obstetrician. On the latter's recommendation, Ms. Cojocaru attempted to deliver her baby by vaginal birth after caesarean section, a procedure commonly known as VBAC. Since Ms. Cojocaru was ten days overdue, she was admitted to British Columbia Women's Hospital and Health Centre on 21 May 2001 and was induced by Dr. Edris, a medical resident. Dr. Dale Steele was the obstetrician on rotation that day and Nurse Bellini was the attending nurse. During her labour, Ms. Cojocaru experienced a uterine rupture, which had the effect of restricting

Alain Roussy is an assistant professor at the Faculty of Law, University of Ottawa (Common Law Section, French program). The author would like to thank Marie-France Boyer (JD student, University of Ottawa) for her able research assistance made possible by a grant provided by the Law Foundation of Ontario. The author would also like to thank the article's anonymous reviewer for the very helpful comments.

2013 SCC 30, [2013] 2 SCR 357 [Cojocaru].

Cojocaru (Guardian Ad Litem) v British Columbia Women's Hospital, 2009 BCSC 494, 65 CCLT (3d) 75.

Cojocaru (Guardian Ad Litem) v British Columbia Women's Hospital and Health Center, 2011 BCCA 192 [Cojocaru (BC CA)].

Cojocaru, supra note 1 at para 49. 
her baby's oxygen supply. Though an emergency caesarean section was then performed, it was too late. The baby, Eric Cojocaru, suffered brain damage and was also later diagnosed with cerebral palsy.

Eric Cojocaru and his mother sued the above doctors, nurse, and hospital. ${ }^{5}$ At trial, the plaintiffs were awarded over \$4 million after the trial judge found that the defendants were liable in negligence. His reasons consisted of 368 paragraphs, 321 of which were copied without acknowledgment — from the plaintiffs' submissions, leaving 47 paragraphs that were "predominantly in the judge’s own words."6

\section{THE COURT OF APPEAL's DECISION}

The majority of the Court of Appeal for British Columbia, Justices Levine and Kirkpatrick, concluded that a new trial had to be ordered "in this most troubling appeal." ${ }^{\text {"In }}$ their view, the reasons for judgment had to be rejected "because they cannot be taken to represent the trial judge's analysis of the issues or the reasoning for his conclusions.” 8 More specifically, according to the majority of the Court of Appeal, "[t]he form of the reasons, substantially a recitation of the respondents' [plaintiffs] submissions, is in itself 'cogent evidence' displacing the presumption of judicial integrity, which encompasses impartiality."’ The majority also found that the reasons did "not meet the functional requirement of public accountability” and did "not allow for meaningful appellate review."10

In dissent, Justice Smith held that "there is nothing inherently wrong with adopting the submissions of a party in whole or in part as reasons for judgment so long as those submissions truly and accurately reflect the judge's own independent analysis and conclusions." 11 In the context of this case, he found that there were sufficient "signs in the reasons that the trial judge applied his mind to the issues"12 so that "the presumption that the reasons for judgment reflect the reasoning that led the trial judge to his decision has not been displaced." ${ }^{13}$ However, after reviewing the merits of the case, Justice Smith would have dismissed the case as against all defendants except Dr. Yue and would have reduced the award for damages. As we shall see, Justice Smith's analysis largely prevailed at the Supreme Court.

\section{The SUPREME CourT’s DECISION}

Chief Justice McLachlin wrote the Court's decision for a unanimous full bench. The Court first addressed head-on the main question of whether extensive copying from one party's

5 There were a number of others initially sued as well, but only the claims against these survived all the way to the Supreme Court.

Cojocaru, supra note 1 at para 10. The use of the term "predominantly" is explained in the Court of Appeal's decision where it was found that of the 47 remaining paragraphs, seven were a mix of the plaintiffs' submissions and the judge's own words thus leaving only 40 paragraphs that could truly be said to be in the judge's own words only. Cojocaru (BC CA), supra note 3 at para 20.

Cojocaru (BC CA), ibid at para 107.

Ibid at para 111 .

Ibid at para 127.

Ibid at para 128.

Ibid at para 30 .

Ibid at para 22.

Ibid at para 29. 
submissions meant that a decision should be set aside. The Court started its analysis by pointing out that the issue before it regarding copying was one of potential procedural error and not one of potential substantive error. ${ }^{14}$ In other words, the complaint targets the fairness of the process and whether the judge decided the issues impartially, not whether the decision is correct on the merits. Viewed in this light, the Court found that the starting point for the analysis lay in applying its previous decision $R v$. Teskey. ${ }^{15}$ According to the Court, the question was, therefore, "whether a reasonable person would conclude that the alleged deficiency, taking into account all relevant circumstances, is evidence that the decisionmaking process was fundamentally unfair, in the sense that the judge did not put her mind to the facts, the arguments and the issues, and decide them impartially and independently."16 The evidence that is required must be "cogent." ${ }^{\text {"T }}$ This is so because judges benefit from a "high" 18 presumption of integrity and impartiality that carries considerable weight. ${ }^{19}$

The Court nicely summarized the applicable principles as follows:

\begin{abstract}
The basic framework for assessing a claim that the judge failed to decide the case independently and impartially may be summarized as follows. The claim is procedural, focussing on whether the litigant's right to an impartial and independent trial of the issues has been violated. There is a presumption of judicial integrity and impartiality. It is a high presumption, not easily displaced. The onus is on the person challenging the judgment to rebut the presumption with cogent evidence showing that a reasonable person apprised of all the relevant circumstances would conclude that the judge failed to come to grips with the issues and decide them impartially and independently. ${ }^{20}$
\end{abstract}

The Court rejected rather swiftly the argument that copying demands that a "functional" inquiry be made. This inquiry, stemming from the Court's decision in $R v$. Sheppard, ${ }^{21}$ asks whether the reasons are adequate (or sufficient) to fulfill the basic functions of (1) justifying and explaining the result, (2) telling the losing party why he or she lost, (3) providing public accountability, and (4) permitting effective appellate review. ${ }^{22}$ In the Court's view, the complaint in this case was not about sufficiency, "but about process," 23 although sufficiency was argued before it and was the basis for the decision of the majority of the Court of Appeal. ${ }^{24}$

Cojocaru, supra note 1 at para 12.

2007 SCC 25, [2007] 2 SCR 267 [Teskey].

Cojocaru, supra note 1 at para 13 .

Cojocaru, ibid at para 21. The term "cogent” was used in Teskey, supra note 15 at para 21, cited in Cojocaru at para 18.

Cojocaru, ibid at para 20, citing $R v S(R D)$, [1997] 3 SCR 484 at para 32 [S (RD)] ; Wewaykum Indian Band v Canada, 2003 SCC 45, [2003] 2 SCR 259 at para 59 [Wewaykum].

Cojocaru, ibid at para 16, citing Teskey, supra note 15 at para 19.

Cojocaru, ibid at para 22.

2002 SCC 26, [2002] 1 SCR 869 [Sheppard].

Sheppard, ibid at para 24. See also $R v R E M$, 2008 SCC 51, [2008] 3 SCR 3 at para 11 [REM]; $R v$ Walker, 2008 SCC 34, [2008] 2 SCR 245 at para 19 [Walker]; FH v McDougall, 2008 SCC 53, [2008] 3 SCR 41 at para 98 [FH]; Hill v Hamilton-Wentworth Regional Police Services Board, 2007 SCC 41, [2007] 3 SCR 129 at para 100 [Hamilton].

Cojocaru, supra note 1 at para 26.

As already noted, the majority of the Court of Appeal found "that the reasons did not meet the functional requirement of public accountability and, as such, were not amenable to meaningful appellate review." See Cojocaru (BC CA), supra note 3 at para 127. 
The Court then turned its attention to what it would take to displace the presumption of judicial integrity and impartiality. In its view, such evidence may be intrinsic or extrinsic. While intrinsic evidence arises on the face of the reasons themselves, extrinsic evidence comes from outside the four corners of the reasons. ${ }^{25}$ The analysis must be "holistic and contextual." ${ }^{26}$ Turning more specifically to the issue of copying, the Court concluded that the practice, even if done extensively, does not in itself rebut the presumption of judicial impartiality and integrity. Rather, this occurs "only if the copying is of such a character that a reasonable person apprised of the circumstances would conclude that the judge did not put her mind to the evidence and the issues and did not render an impartial, independent decision." ${ }^{27}$ The "character" in question should be considered by taking into account "the nature of the case, what was copied, the extent of the copying, how it functions in the reasons as a whole, and any other relevant circumstances." ${ }^{28}$ In other words, it is not copying per se that will be sufficient to rebut the presumption of judicial integrity and impartiality. The copying must be considered in context along with all other relevant factors.

Not only did the Court conclude that copying was not, in itself, sufficient to reject reasons, it also found that "judicial copying is a long-standing and accepted practice." ${ }^{\text {, } 9}$ In the Court's view, the argument that reasons must be "original” or at the very least explicitly attributed to another source in order to demonstrate that the judge has turned his mind to the issues is simply wrong. ${ }^{30}$ Copying, whether attributed or not, does not necessarily mean that the judge has not decided the issues in an impartial fashion. In the Court's view, judicial copying is fundamentally different from other kinds of copying because judgment writing is a fundamentally different exercise. Writing a judgment is not like writing a school essay, a book, or an academic article where originality and attribution of sources are required. ${ }^{31}$ In fact, lack of originality is "part and parcel of the judicial process"32 as "[j]udgments routinely incorporate phrases and paragraphs from a variety of sources." ${ }^{33}$ These include other judgments, academic articles, submissions of the parties, other judges on the case, and law clerks. $^{34}$

In the Court's view, “[t]he concern about copying in the judicial context is not that the judge is taking credit for someone else's prose, but rather that it may be evidence that the reasons for judgment do not reflect the judge's thinking." ${ }^{35}$ This could lead to the impression that the process has been unfair. The practice of copying, particularly extensive copying, should therefore be discouraged, but that does not lead to the conclusion that a decision must be set aside on that basis alone. ${ }^{36}$ 
The Court acknowledged the growing practice of electronic submissions, which "help the judge get the decision right, facilitate the task of judgment writing and speed the judicial process." 37 Since “[j]udges are busy," copying helps to ensure "that the disputes and legal issues brought before the courts [are] resolved in a timely and effective manner, all the while maintaining the integrity of the judicial process." 38

Looking at cases, both international and domestic, ${ }^{39}$ the Court found general acceptance of the view "that copying is acceptable, and does not, without more, require the judge's decision to be set aside." ${ }^{40}$ It is only when "the incorporation of the material of others would lead a reasonable person apprised of all the relevant facts to conclude that the trial judge has not put his or her mind to the issues and made an independent decision based on the evidence and the law, [that] the presumption of judicial integrity is rebutted and the decision may be set aside." 41

Applying this principle to the facts in this case and considering various factors in determining the "character" of the copying, the Court found that the defendants had failed to meet the high onus of establishing that the trial judge had not dealt with the issues in an impartial fashion. Regarding the extent of the copying, the Court found that it was true that the copying in this case was extensive, but the trial judge did write some paragraphs in his own words and did make some findings that were contrary to the party from whom he copied. ${ }^{42}$ Regarding the quality of the copying, it was true that an error contained in the submissions of the plaintiffs had found its way into the reasons of the trial judge, but the error in question was technical in nature ${ }^{43}$ and not one of substance. ${ }^{44}$ It was also true that the judge had failed to address at least some of the defendants' criticism of the plaintiffs' arguments as well as many of the defendants' submissions, ${ }^{45}$ but trial judges are not "required to discuss every argument or alleged problem in arriving at a particular conclusion."46 Regarding the lack of attribution, the Court responded bluntly that judges are "not expected to be original" and that, in any event, attributed copying and non-attributed copying are both copying in that a judge has taken material from someone else. ${ }^{47}$ Regarding the nature of the case, the Court found that the present case, a considerably complex civil one, fell somewhere between a criminal case that demands "the high level of scrutiny described in Teskey" and straightforward civil motions. ${ }^{48}$ According to the Court, complex cases call for the trial judge

Ibid at para 34

Ibid at para 37.

The first case considered is an English Court of Appeal case, English v Emery Reimbold \& Strick Ltd, [2002] EWCA Civ 605, [2002] 3 All ER 385 [Emery]. The Court presents this case as being the leading English case on the matter establishing that "copying does not invalidate a decision" (Cojocaru, ibid at para 38). It also reviews a British tribunal decision, Meadowstone (Derbyshire) Ltd v Kirk, 2006 WL 690588 (UK Employment Appeal Tribunal) and a Hong Kong Court of Appeal decision, Shin v Kung, [2004] HKCA 205, that applied the Emery case. Interestingly, the Emery case was not referred to in the factum of any party or intervener or the reasons of the Court of Appeal. In addition, on the author's reading of the case, it does not stand for the proposition stated by the Court. Rather, the Emery case is akin to the Canadian Sheppard case, supra note 21, and deals with the adequacy of reasons.

Cojocaru, ibid at para 37.

Ibid at para 49.

Ibid at paras 53-55.

The date of a letter.

Cojocaru, supra note 1 at para 58 .

Ibid at paras 59-62.

Ibid at para 60 .

Ibid at para 65.

Ibid at para 67. 
to depart more boldly from the submissions of the parties compared to simple civil matters where copying may be "uncontroversial." ${ }^{49}$ Despite the fact that the trial judge in the present case did not adhere to "best practices," ${ }^{50}$ the Court found that he had not "failed to put his mind to the critical issues and decide them independently and impartially." 51 The defendants had also argued that the functional requirements of the reasons had not been fulfilled. Based on its reasoning, as described above, the Court found that the functional analysis was not applicable in the present case. ${ }^{52}$

In concluding on the issue of copying, the Court found that "it would have been preferable for the trial judge to discuss the facts and issues in his own words." ${ }^{33}$ However, according to the Court, that is not sufficient to set aside a decision; more is required:

To rebut the presumption of judicial integrity, the defendants must establish that a reasonable person apprised of all the circumstances would conclude that the trial judge failed to consider and deal with the critical issues before him in an independent and impartial fashion. The defendants have not done so. ${ }^{54}$

Having decided that the decision should not be set aside on the basis of extensive copying, the Court then turned its attention to the merits of the case. It is here that the defendants were more successful, but, in the end, not successful enough to change the final outcome. As counsel for the plaintiffs frankly acknowledged during the oral hearing, "at the end of the day, I need a judgment so that this child can get the care that he needs ... whether it's against one or everybody is immaterial." 55

The trial judge had found Dr. Edris liable for inducing labour without first "ascertaining the orientation of Ms. Cojocaru's uterine scar."56 This is because having a uterine scar that is not low transverse is contraindicated for induction. In fact, however, Ms. Cojocaru's scar was indeed low transverse and so induction was proper medical practice. ${ }^{57}$ In addition, the trial judge also found that there was no evidence that the induction had caused the rupture. ${ }^{58}$ Thus, even if Dr. Edris had failed to properly ascertain the orientation of the uterine scar, there was no causal link between that omission and the eventual rupture. ${ }^{59}$

As for Dr. Steele, the obstetrician on rotation that fateful day, the trial judge had found him liable for not having assessed Ms. Cojocaru earlier that day and for not having attended immediately upon learning of the rupture. ${ }^{60}$ According to the trial judge, however, there was nothing to suggest that Dr. Steele had not followed prevailing medical practice in not assessing her earlier in the day. After all, there was no indication of an impending uterine rupture at that time. As for not having attended immediately upon the occurrence of the

Supreme Court of Canada, "Webcast of the Hearing on 2012-11-13," online: <bit.ly/1DimE8P> at $108 \mathrm{~m}: 35 \mathrm{~s}$

Cojocaru, supra note 1 at para 102.

At least at the time.

Cojocaru, supra note 1 at para 104.

Ibid at paras 102-104.

Ibid at para 106. 
rupture, the trial judge found that even if Dr. Steele had done so, the outcome would have been the same in light of the fact that no operating room was available at that moment to allow a caesarean section to be performed. ${ }^{61}$ This lack of an available operating room also absolved Nurse Bellini (and the hospital) of any liability. The Court found that even if she had called Dr. Steele fifteen minutes before the call was eventually placed, as the trial judge found that she should have, the same result would have occurred. ${ }^{62}$

A similar causation analysis prompted the Court to throw out two of the three findings of liability against the primary defendant, Dr. Yue. The trial judge had found Dr. Yue negligent in recommending the VBAC procedure to Ms. Cojocaru without first ascertaining the orientation of the previous uterine scar. Like induction, VBAC is contraindicated in patients with certain forms of uterine scars, but not when the scar is low transverse. Since Ms. Cojocaru's scar was in fact low transverse, the Court found that, despite Dr. Yue's omission, "no causal connection was established between the negligence alleged and the injury."63 Similarly, the trial judge had found Dr. Yue liable for her failure to obtain her patient's informed consent to induction. In the Court's view, there was "no evidence to support a causal relationship between the induction and the harm suffered.”64

It is on the question of informed consent to the VBAC procedure itself, however, that the defendants — or Dr. Yue, in particular — met their Waterloo. The trial judge had found Dr. Yue negligent in this regard and the Court agreed. Dr. Yue had testified that she had an "invariable routine" of discussing risks of VBAC with patients. ${ }^{65}$ Ms. Cojocaru's chart also indicated that "modes of delivery were discussed"66 and that the patient "wants VBAC."67 A letter from Dr. Yue to Ms. Cojocaru's referring physician also noted various VBAC statistics and risks. All these bits of evidence in Dr. Yue's favour, however, were insufficient for the trial judge who opted to prefer the evidence of Ms. Cojocaru who claimed that she had not been properly informed of the risks of VBAC. Though the Court found that the trial judge had made a number of errors in assessing the evidence on this point, including misstating the content of the chart and erring in his assessment of the consultation letter, these errors were not serious enough to overturn his finding that the risks were not sufficiently conveyed to Ms. Cojocaru. Finally, the Court also noted that Dr. Yue's incorrect assumption about the reason for the previous caesarean section ${ }^{68}$ also meant that she could not have properly informed Ms. Cojocaru of the risks of VBAC in her particular circumstances. $^{69}$ Thus, Dr. Yue was found liable for failing to obtain Ms. Cojocaru's informed consent regarding VBAC. ${ }^{70}$

Ibid at paras 105-109.

Ibid at paras $110-15$.

Ibid at para 84-85.

Ibid at para 98.

Ibid at para 90.

Ibid.

Ibid at para 91.

She had assumed that the procedure was elective when in fact it had been undertaken for failure to progress (ibid at para 95).

Ibid at paras 94-95.

Ibid at para 96 . 
In terms of damages, the Court found "no palpable and overriding error that would justify [its] intervention." ${ }^{\prime 11}$ The plaintiffs were therefore awarded the slightly over $\$ 4$ million damages as calculated by the trial judge. After all was said and done on the merits of the case, the single finding of liability that stuck against Dr. Yue was enough to give the plaintiffs the judgment they sought.

\section{ON THE DECISION GENERALLY}

In my view, the fundamental takeaway of the decision - that copying is generally fine, but should be discouraged and can be a factor in determining whether a reasonable person apprised of the circumstances would conclude that the judge did not put his mind to the evidence and the issues and did not render an impartial decision — is entirely appropriate. I therefore join those who have generally cheered ${ }^{72}$ the decision rather than jeered it. ${ }^{73}$ In deciding as it did, the Court chose pragmatism over idealism. As the Court stated, "[i]n an ideal world, one might dream of judges recasting each proposition, principle and fact scenario before them in their own finely crafted prose., ${ }^{, 4}$ In an ideal world, judges would also have all necessary time to do such crafting, while simultaneously being able to render swift justice. The reality, however, is quite different. As every student who has written a school essay, or professor who has written an academic article knows, choosing every word, paraphrasing someone else's words so as not to be quoting too much, and making sure that every passage is properly attributed can be an extremely time-consuming and exhausting process. In cases of essays and articles, however, it is a necessary pain because the author must produce an original product. That should not be the expectation, however, for judges because judges aren't being rewarded for being original, like a student trying to obtain a grade or a professor trying to get tenure. As Justice Smith stated in his dissent at the Court of Appeal, "[t]rial judges are busy, and there can be cases ... where a party's submissions so accurately reflect the trial judge's reasoning that nothing would be gained by postponing other pressing work in order to rewrite the reasoning and conclusions in the judge's own words." ${ }^{\text {"75 }}$ This is not to say that putting pen to paper does not have advantages. As Justice Binnie noted in Sheppard, "it is widely recognized that having to give reasons itself concentrates the judicial mind on the difficulties that are presented. ${ }^{, 76}$ He then added that "[t]he absence of reasons, however, does not necessarily indicate an absence of such concentration." ${ }^{77}$ The same can be said of copied reasons, whether attributed or not. This is

Ibid at para 120 .

See e.g. Victor Yee, “Supreme Court of Canada condones copying in Cojocaru” (10 September 2013) The Court (blog), online: <www.thecourt.ca/2013/09/10/supreme-court-of-canada-condones-copying-incojocaru/> ("the Supreme Court of Canada ... has chosen to acknowledge the realities of legal practice and the function of judiciaries").

See e.g. Emir Crowne, “Judicial ‘Copying’ Does Not Affect Independence or Impartiality” (2013) 8:11 J Intell Prop L \& Prac at 835 ("[t]he unattributed judicial incorporation of [written submissions of counsel] into judgments is not only plagiarism, but a breach of copyright and moral rights”); Ryan Teschner, "Don’t Explain Yourself: SCC Minimizes the Importance of Reasons for Decision” (22 September 2013) Standardless Review (blog), online: Heenan Blaikie LLP <www.standardlessreview. com/dont-explain-yourself-scc-minimizes-the-importance-of-reasons-for-decision> ("[i]f reasons for decision become nothing more than an exercise in fill in the blanks or a series of paragraphs lifted from another source, we are simply creating assembly line justice”).

Cojocaru, supra note 1 at para 37.

Cojocaru (BC CA), supra note 3 at para 30.

Sheppard, supra note 21 at para 23. See also REM, supra note 22 at para 12 . See generally Chad M Oldfather, "Writing, Cognition, and the Nature of the Judicial Function” (2008) 96:4 Geo LJ 1283.

Sheppard, ibid at para 23. 
not to say that copying is good practice; and this is not to say, either, that copying should not even be a consideration when determining whether the judge acted impartially — which is the position at the other end of the spectrum that was advocated by the Attorney General for Ontario. ${ }^{78}$ In a hypothetical scenario in which a judge did not act impartially, it could very well be the case that some evidence of bias can be found in the copied reasons. For this reason, the Court wisely chose not to close the door entirely to considering copying in the overall assessment of impartiality.

So what is the message that the Court is sending to judges? Something along the following lines: you are busy - we get it. ${ }^{79}$ Copying is not a good idea, ${ }^{80}$ but if it can help expedite judicial business, ${ }^{81}$ go ahead. Don't carry it to excess ${ }^{82}$ though, as it may lead to questions about your impartiality.

\section{ON THE MESSAgE TO LAWYERS}

Lawyers are there to help the courts or at least they're supposed to. In its factum and oral submissions, the Attorney General for Ontario argued forcefully that lawyers are trained to write submissions so that they can be adopted as reasons and, in fact, want judges "to borrow prose from their factum." ${ }^{83}$ He also reminded the Court that it is a "high compliment to counsel when reasons echo their prose, attributed or not." ${ }^{84}$ Alarm bells have been raised, however, regarding the partisanship of written submissions. In a recent Federal Court of Appeal case, ${ }^{85}$ Justice Nadon viewed written submissions with a bit of scepticism:

One must bear in mind that when parties file written submissions, they do not have to make allowances for the other side's case. Specifically, parties tend to maximize the strong points of their case and to minimize their weaknesses. It is up to the Judge, after careful consideration of all the evidence and the arguments, to draw the line at the appropriate place. ${ }^{86}$

The above concern is valid, but it does not lead to the conclusion that all copying is a bad idea. It simply leads to the conclusion that copying from bad written submissions is a bad idea. Indeed, when written submissions are drafted in such a way that facts are bent, opposing arguments are twisted, cases are cited to advance propositions for which they do

78 An intervener in the case.

79 Cojocaru, supra note 1 at para 37.

$80 \quad$ Ibid at para 36.

$81 \quad$ Ibid at para 34

$82 \quad$ Ibid at para 30.

83 Ibid (Factum of the Attorney General for Ontario at para 6 [Factum AGO]).

$84 \quad$ Factum AGO, ibid at para 8. As one author put it: "I tell my first-year legal writing students truthfully that I knew I had written the best brief I possibly could on a motion when the court's opinion announcing its decision was directly cut-and-pasted from my brief” (Peter Friedman, "What Is a Judicial Author?” (2011) 62:2 Mercer L Rev 519, 529-30).

85 Janssen-Ortho Inc $v$ Apotex Inc, 2009 FCA 212, 392 NR 71 at para 78. This case was cited by the Supreme Court in Cojocaru, supra note 1 at para 48, but not on this point.

$86 \quad$ Ibid. A similar view was expressed by the Alberta Court of Appeal in University of Alberta $v$ Chang, 2012 ABCA 324, 539 AR 58 [Chang] ("Because they are prepared in an adversarial context, the briefs of the parties tend to be 'one-sided.' They generally tend to place the position of that litigant in the best possible light, and downplay (or even ignore) the arguments, authorities, and evidence in support of the opposite side" at para 21). Similarly, in an American case: "A district judge could not photocopy a lawyer's brief and issue it as an opinion. Briefs are argumentative, partisan submissions. Judges should evaluate briefs and produce a neutral conclusion, not repeat an advocate's oratory" (DiLeo v Ernst \& Young, 901 F2d 624 (7th Cir 1990) at 626). 
not actually stand, and legal reasoning is sketchy, then those written submissions should simply not be copied. Accepting that judges can copy does not mean accepting that judges can copy blindly. It means that judges should copy only when the written submissions are of such quality that writing that particular part of the reasons from scratch would be a waste of time. As the Attorney General for Ontario put it:

\begin{abstract}
A factum is a great source for prose for judicial reasons even though it is partisan advocacy. Good factumdrafting uses the same principles as drafting judicial reasons. Competent factums don't misstate facts or law and don't invite fact findings unsupported by evidence. A good factum identifies and addresses contrary evidence, cases and arguments. Competent counsel ensures a factum is error-free. They don't want to induce reversible error. ${ }^{87}$
\end{abstract}

Though the Court did not explicitly reject the sceptical view expressed by Justice Nadon above, its decision obviously implies that it is of the view that, at least sometimes, there are good written submissions - good enough to be copied. The Court's decision can, therefore, be read as a vote of confidence in the role of lawyers in the judicial process. At the very least, it is a strong signal to the profession that good — that is, balanced, fair, and complete written submissions are to be encouraged because they now have the top court's blessing to become reasons. In this regard, the Court mentioned with approval the growing phenomenon of parties submitting written arguments and proposed orders to courts in an electronic format. ${ }^{88}$ This has the advantage of reducing the time for "retyping as portions of one document can be easily transferred to another using the cut-and-paste operation of word processing software." ${ }^{\text {"9 }}$ Wise counsel will want to keep in mind the Cojocaru decision and take advantage of electronic filings by ensuring more than ever that their submissions are ready to be adopted as reasons.

\title{
VII. On the Message to Medical Professionals
}

Though the Cojocaru decision will not be overly significant from a medical negligence or general tort perspective, there is nonetheless a very important lesson to be learned from it for medical professionals. The lesson is to document interactions better with patients regarding informed consent. The Supreme Court's leading decision on informed consent was decided many years ago and deals with what must be discussed between doctor and patient. ${ }^{90}$ When it comes to litigation, however, attention will turn to evidence that the discussion in fact occurred the way the doctor says it did. According to the Canadian Medical Protective Association (CMPA), "[a]llegations of inadequate consent and the failure to adequately document the consent discussion are recurring themes in CMPA medico-legal cases."91 Detailed contemporaneous notes are an extremely useful defensive shield against claims that consent was not fully informed and should be part of every medical professional's daily practice. Not surprisingly, the CMPA encourages doctors to do just that. ${ }^{92}$ However,

Factum AGO, supra note 83 at para 11.

Cojocaru, supra note 1 at para 34 .

Ibid at para 34, citing Gregory M Silverman, "Rise of the Machines: Justice Information Systems and the Question of Public Access to Court Records over the Internet” (2004) 79:1 Wash L Rev 175 at 196. Reibl $v$ Hughes, [1980] 2 SCR 880.

CMPA, Informed Consent (2013), online: CMPA < https://oplfrpd5.cmpa-acpm.ca/documents/10179/ 300031190/ informed_consent-e.pdf $>$.

See e.g. ibid. 
consideration could also be given by the CMPA and prudent doctors to go beyond simply documenting, and adopt a practice of having patients sign consent forms or, a practice that is not uncommon in the legal community, following up conversations with confirmation or reporting letters sent directly to the patient.

\section{ON THE DECISION’s SHORTCOMINGS}

One aspect that the Court did not address as a rationale for generally accepting the practice of copying is that of access to justice. As most legal observers in the country know, much attention has been given to this topic in the last few years, and Chief Justice McLachlin has certainly played an important role in putting the spotlight on the issue. ${ }^{93}$ The Trial Lawyers Association of British Columbia ${ }^{94}$ (TLABC) had raised the issue of access to justice in its written submissions. In the TLABC's view, the presumption of integrity needs to be kept high so that appeals and retrials would not become too frequent and overburden an already too slow justice system. ${ }^{95}$ In my view, this is a solid argument. In addition, attacking reasons solely because of some copying or lack of attribution on the judge's part, something over which the parties to the litigation have no control, would be easy for moneyed parties, but would drag impecunious ones into appeals and possible retrials, as occurred in the present case $^{96}$ This view on the role of access to justice in the copying context is shared by some ${ }^{97}$ but not all legal commentators. ${ }^{98}$ Some are of the view that allowing copying by judges shifts the cost and burden of judgment writing to the parties. ${ }^{99}$ In my view, not only is this cost recoverable by way of cost awards, ${ }^{100}$ but there should be little if any additional costs since good counsel already draft submissions with the view — and the hope - that they will be adopted as reasons, as already discussed.

On an entirely different point, it is unfortunate that when it came time to detailing its analysis and then applying it to the facts in this case, the Court left much to be desired. As already noted, the Court concluded that the presumption of judicial impartiality and integrity is rebutted "only if the copying is of such a character that a reasonable person apprised of the circumstances would conclude that the judge did not put her mind to the evidence and the issues and did not render an impartial, independent decision." 101 The "character" in question should be considered, according to the Court, by taking into account the following five

93

See e.g. “Canada’s top judge slams ‘inaccessible justice,’” CBC News (18 August 2013), online: <www. cbc.ca/news/canada/saskatoon/canada-s-top-judge-slams-inaccessible-justice-1.1306993>; The Right Honourable Beverley McLachlin, “The Challenges We Face” (Remarks presented at the Empire Club of Canada, Toronto, 8 March 2007), online Supreme Court of Canada <www.scc-csc.gc.ca/courtcour/judges-juges/spe-dis/bm-2007-03-08-eng.aspx>.

An intervener in the case.

Cojocaru, supra note 1 (Factum of the TLABC at para 16).

Counsel for the plaintiffs tactfully pointed out towards the beginning of his oral submissions, that "the legal issue [before the Court] sits outside the legal dispute between the parties," that it is an issue that his clients "had no control over" and that they "don't understand, quite frankly." See video of oral hearing, supra note 55 at $93 \mathrm{~m}: 15 \mathrm{~s}$.

$97 \quad$ See e.g. Yee, supra note 72.

98 See e.g. Jonnette Watson Hamilton, “"Judges of first instance are not mere scribes, collators of evidence, collage artists, or way stations on the road to justice': The Problems with Copy-and-Paste Judgments" (18 December 2012) Ablawg.ca (blog), online: <ablawg.ca/2012/12/18/judges-of-first-instance-are-notmere-scribes-collators-of-evidence-collage-artists-or-way-stations-on-the-road-to-justice-the-problemswith-copy-and-paste-judgments-jon/>.

$99 \quad$ Ibid.

$100 \quad$ As noted by Yee, supra note 72.

$101 \quad$ Supra note 1 at para 36. 
factors: (1) the nature of the case; (2) what was copied; (3) the extent of the copying; (4) how it functions in the reasons as a whole; and (5) any other relevant circumstances. ${ }^{102}$

At least three points can be made here. First, the Court did not consider or even explain all of the five factors it listed. This is so because it instead chose to address the five arguments advanced by the defendants: the extent of the copying; the quality of the copying; the lack of attribution; the nature of the case; and the failure to fulfill the basic functions of reasons. ${ }^{103}$ Some of these arguments correspond to the factors listed by the Court, but the correspondence is obviously not perfect and, unfortunately, the Court chose not to clarify further how its forgotten factors should be considered and applied. ${ }^{104}$

Second, of the defendant's three arguments that do not correspond to the five factors listed by the Court, two of them (lack of attribution and failure to fulfill the basic functions of reasons) were quickly batted down by the Court, ${ }^{105}$ but the third (quality of the copying) was considered at length. ${ }^{106}$ Though the Court eventually rejected the argument — which was, in fact, comprised of three separate sub-arguments ${ }^{107}$ — its discussion of it leads one to believe that the quality of the copying is an additional relevant factor. ${ }^{108}$ Further, in concluding that the defendants had not established that the presumption should be rebutted, the Court relied heavily on the fact that the trial judge had "rejected some of the plaintiffs' key submissions." ${ }^{109}$ Clearly then, this is another relevant factor. The point here is not that the Court's factors are wrong, but that the Court did not fully articulate their application and could have provided a more fulsome list that would have been more helpful to an eventual reviewing court placed in a similar position.

A more comprehensive list of factors to take into account when determining whether reasons should be set aside in such cases would include the following: ${ }^{110}$

$102 \quad$ Ibid at para 51.

$103 \quad$ Ibid at para 52.

104 In particular, they are "what was copied" and "how it functions in the reasons as a whole."

105 Supra note 1 at paras 65-66 and 71-72, respectively.

$106 \quad$ Ibid at paras 56-63.

107 Namely, that an error contained in the copied material had been adopted in the reasons, that the trial judge had not addressed the defendants' criticism of the plaintiffs' arguments on causation, and that the trial judge had not considered virtually any of the defendant's submissions: see ibid at paras 56-63. The Court specifically held that if the error that had been incorporated in the copied reasons had "been one of substance [rather than technical], this would be troubling”: see ibid at paras 58.

Ibid at para 74 .

110 Some of the listed factors, in particular, factors 6, 10,13 and 14 are similar to factors that could be relevant in an adequacy analysis done under Sheppard, supra note 21 . In this author's view, this is inevitable, and the Court's attempt in Cojocaru to put the Sheppard and Teskey lines of cases in separate silos may be helpful from an analytical perspective, but not strictly correct. The fact that reasons are inadequate, or somewhat so (and it is argued below that reasons should be adequate in the civil context) is a relevant factor in determining whether the presumption of integrity and impartiality should be rebutted. Admittedly, the lines of cases can often be considered separately because the non-fulfillment of the adequacy requirements can, on its own, permit a reviewing court to reject reasons. However, if the reasons raise concerns from an adequacy perspective, but not sufficiently to conclude that the Sheppard test has not been met, it is not clear why those concerns would not be a relevant factor in a Teskey analysis. If the Court had adopted such an approach, its analysis could have been beneficially influenced by the Sheppard line of cases, including very recent Alberta cases that dealt with adequacy issues in the copying context (see Fuller Western Rubber Linings Ltd v Spence Corrosion Services Ltd, 2012 ABCA 137, 524 AR 246; Chang, supra note 86; Briggs Bros Student Transportation Ltd v Alberta (Attorney General), 2012 ABCA 386, [2012] AJ No 1261 (QL)). Generally speaking, it must be noted that the Court's review of relevant cases in Cojocaru was rather cursory. There are a number of additional relevant cases, such as those above, that could have been cited and analysed by the Court and that would have assisted it in developing a more robust analysis. Another such case is the Australian Federal Court decision in LVR (WA) Pty Ltd v Administrative Appeals Tribunal, [2012] FCAFC 90, 203 
(1) The nature of the case: is the case straightforward or complex? ${ }^{111}$

(2) What was copied: did the copied material consist of uncontested facts or standard legal fare or did it consist of heavily contested facts or novel legal analysis?

(3) The extent of the copying: were a few sentences or paragraphs copied or was the copying extensive?

(4) How the copying functions in the reasons ${ }^{112}$

(5) Errors or inconsistencies brought into the reasons by copying: were the errors or inconsistencies technical in nature or were they errors of substance?

(6) Submissions of the other party: were the various submissions of the party from whom little or no copying was done addressed (or even adopted) or not?

(7) Submissions not adopted: were there significant submissions of the party from whom much copying was done that were not adopted or were they all or virtually all adopted?

(8) What is original: is the original prose extensive and substantive or limited and insignificant? ${ }^{113}$

(9) Findings of fact: are the findings of fact sound when compared to the record or not? ${ }^{114}$

(10) Findings of credibility: are such findings sufficiently explained or not? ${ }^{115}$

(11) Errors of law: are the reasons free of errors of law or not?

FCR $166[$ LVR(WA)] where relevant international cases were reviewed and a list of relevant factors was developed.

111 Note that there is an argument to be made that copying should, in fact, be more acceptable in cases involving "difficult scientific concepts or issues of a highly technical nature, such that the court might reasonably be expected to need the parties' assistance in describing or explaining them”: see Douglas R Richmond, “Unoriginal Sin: The Problem of Judicial Plagiarism” (2014) 45:3 Ariz St LJ 1077. Cojocaru, supra note 1 at para 51. This factor was explicitly noted by the Court, though it was not further explained. It is unclear what the Court was trying to convey here and in what way this factor differs from the "what was copied" factor.

113 The day before Cojocaru was released by the Supreme Court, the English and Wales Court of Appeal released Crinion v IG Markets Ltd, [2013] EWCA Civ 587, [2013] Alll ER (D) 272. In that case, approximately 94 percent of the reasons had been copied from one of the parties' submissions. The Court embarked upon a detailed analysis of the reasons, comparing them to the submissions, in order, among other things, to try to identify where the trial judge had ventured out on his own. In the end, though the Court publicly scolded the trial judge for his extensive copying, it concluded "that enough can be teased out of the judgment to satisfy the legitimate demand of the Appellants for reasoning which deals with their respective cases otherwise than through the prism of the Respondent's argument” (at para 40).

114 See Richmond, supra note 111 at 1078.

115 This factor had been suggested by the Canadian Bar Association (CBA): see Cojocaru, supra note 1 (Factum of the CBA at para 25). In LVR (WA), supra note 110, the Australian Federal Court held, at paras 90 and 92, that when copied paragraphs relate to issues of credibility, closer scrutiny is appropriate and necessary. 
(12) Argumentative language: was such language eliminated from or incorporated into the reasons? ${ }^{116}$

(13) Citations: are the reasons supported by appropriate citations to the record and appropriate and up-to-date legal authority or not? ${ }^{117}$

(14) The length of the reasons: are the reasons of an appropriate length in the circumstances of the case or are they unreasonably short (or long)?

(15) The source of the content: does the copied material come from another decision or a disinterested party or does it come from one of the parties to the litigation? ${ }^{118}$

(16) Any other intrinsic factors

(17) Any other extrinsic factors. ${ }^{119}$

Third, the way in which the Court considered the various arguments relating to the application of the principles to the facts of the case made it look as if they were not dealing with true factors, but rather a series of elements that had to be ticked off. On a number of occasions, the Court noted the particular criticism it was dealing with was not decisive "in itself,"120 “inconclusive" ${ }^{\prime 121}$ or did not, "without more," however, is the point of having a series of factors. No one factor is required to be conclusive in itself. All factors must be considered and then weighed together, not independently. As the Court itself noted, the analysis must be "holistic and contextual," 123 something it should have been better at demonstrating that it was actually doing.

Thus, it would have been more helpful for the Court to articulate better the factors it specifically recognized, to identify a longer list of factors, and to consider all factors holistically. In the end, such an analysis may often add up to being an elaborate smell test, but the more objective one can make it, the better.

\section{ON JUDICIAL ETHICS}

Ethical Principles for Judges, ${ }^{124}$ published by the Canadian Judicial Council, ${ }^{125}$ is the closest thing that judges have to a code of conduct without it actually being one. ${ }^{126}$ Five basic

This factor had been suggested by the CBA: see Factum of the CBA, ibid at para 25.

See Richmond, supra note 111 . See also LVR (WA), supra note 110 at para 92.

Mentioned as a factor in LVR (WA), ibid at para 92.

Teskey, supra note 15 at para 23 provides a good starting list. Another noteworthy factor mentioned in LVR (WA), ibid at para 92 is that of the function of the decision-maker and the source of that function, a factor which is likely more relevant in an administrative context.

Cojocaru, supra note 1 at para 54.

Ibid at para 62.

Ibid at para 60 .

Ibid at para 29.

Canadian Judicial Council, Ethical Principles for Judges (Ottawa: Canadian Judicial Council, 1998) [Ethical Principles].

The Council is chaired by Chief Justice McLachlin.

It provides specifically that "The Statements, Principles and Commentaries are advisory in nature.... They are not and shall not be used as a code or a list of prohibited behaviours. They do not set out standards defining judicial misconduct” (Ethical Principles, supra note 124 at 3). 
ethical principles are discussed therein: judicial independence; integrity; diligence; equality; and impartiality. Unfortunately, the Court opted to make no reference whatsoever to Ethical Principles in its decision. The Court does not get to pronounce itself on issues affecting judicial ethics every day. When it does get the opportunity, one would think that it would opt to cite the main non-jurisprudential source on the topic of judicial ethics in Canada. Justice Smith at the Court of Appeal did so in this case. ${ }^{127}$ So did the Supreme Court in most prior cases dealing with judicial ethics. ${ }^{128}$ The omission in the Cojocaru case is particularly regrettable because reference to Ethical Principles could perhaps have encouraged the Court to clarify further some of the fundamental ethical principles at play and avoid unfortunate terminology.

In Teskey, Justice Charron, for the majority, held that the presumption regarding judges is that they will act with integrity, "which in turn encompasses the notion of impartiality,"129 and carry out their duties in accordance with their oath of office. ${ }^{130}$ In dissent, Justice Abella held that there is, in addition to the above, a presumption that judges possess the requisite legal knowledge. ${ }^{131}$ As a source for this proposition, she cited a previous unanimous decision of the Court, in which Justice McLachlin (as she then was) held that "[t]rial judges are presumed to know the law with which they work day in and day out." "132 Though Justice Abella did not say so, a quick look at Ethical Principles reveals that the duty to have and maintain the requisite legal knowledge is part of the ethical principle of diligence, ${ }^{133} \mathrm{a}$ principle which seems to attract less jurisprudential attention. The two previous cases which form important parts of the foundation for Teskey are along the same general lines. In $S$. (R.D.) a fractured Court made various references to a presumption of either integrity, ${ }^{134}$ impartiality, ${ }^{135}$ or sometimes both. ${ }^{136}$ In Wewaykum, the Court spoke of a presumption of impartiality only, not integrity. ${ }^{137}$

Turning back to Cojocaru, then, the Court was quite consistent in holding that the presumption in question was one of impartiality and integrity, though it did sometimes refer only to integrity. ${ }^{138}$ More important than these simple lapses, however, is the way the Court chose to craft the exact test to be met. According to the Court,

[t]he onus is on the person challenging the judgment to rebut the presumption [of judicial integrity and impartiality] with cogent evidence showing that a reasonable person apprised of all the relevant circumstances would conclude that the judge failed to come to grips with the issues and decide them impartially and independently. ${ }^{139}$

Cojocaru (BC CA), supra note 3 at para 9.

See Teskey, supra note 15 at para 31; Wewaykum, supra note 18 at paras 59, 84; $S(R D)$, supra note 18 at paras 35, 119; Arsenault-Cameron v Prince Edward Island, [1999] 3 SCR 851 at para 3. The latter two cases do not refer to Ethical Principles, per se, but its precursor, Canadian Judicial Council, Commentaries on Judicial Conduct (Cowansville: Les Éditions Yvon Blais, 1991).

Teskey, supra note 15 at para 19.

Ibid at para 20.

Ibid at paras 29, 33.

$R v$ Burns, [1994] 1 SCR 656 at 664.

See Ethical Principles, supra note 124, Principles 2, 5.

Supra note 18 at para 28.

Ibid at para 32.

Ibid at para 117.

Supra note 18 at paras 62, 66, 69: the word "integrity” appears only three times in the decision, and never in relation to the presumption.

See e.g. supra note 1 at paras 49, 75.

Ibid at para 22 [emphasis added]. 
In so doing, the Court introduced and put in play yet another principle of judicial ethics: independence. Almost every time the Court referred to independence in its decision, the expression was accompanied by a reference to impartiality. ${ }^{140}$ The Court did not, however, explain what it meant by independence and how the term differed from impartiality. The concern here is not just syntactic. If one must show, in order to rebut the "presumption of judicial integrity and impartiality," that the judge in question failed to come to grips with the issues and decide them impartially and independently, then it follows that there is a presumption of impartiality and also of independence — not forgetting, also, integrity. There is no denying that the concepts are related and somewhat overlapping, but they are treated in Ethical Principles as having distinct meanings. Otherwise, there would be fewer principles. In addition, Canadian jurisprudence, as explained in Valente v. The Queen, draws a distinction between impartiality and independence as separate ethical values. ${ }^{141}$

Adding all of this up, we can conclude that there is a presumption of judicial integrity, impartiality, diligence, and independence. The fifth principle of judicial ethics - equality - can easily be brought into the fold when looking at S. (R.D.) where Justices L'HeureuxDubé and McLachlin (as she then was) held that "[t]he reasonable person ... as a member of the Canadian community, is supportive of the principles of equality."142 Surely judges fit into this category as well, and so, there must also be a presumption of judicial equality.

In my view, it would therefore be simpler and more accurate to state that judges benefit from a high presumption that they act in accordance with all principles of judicial ethics; the onus is on the party challenging the decision to present cogent evidence that a reasonable person who is reasonably informed about all the relevant circumstances would apprehend that the presumption is rebutted.

Another judicial ethics point that is raised by the Cojocaru decision, but that can only be mentioned in passing here, is the question of whether the incorporation of copied material in reasons could constitute misconduct of the kind that would attract the attention of the Canadian Judicial Council. Though, in my view, this is unlikely, ${ }^{143}$ it is in theory possible since the question before a reviewing court as in Cojocaru (rejecting reasons) would not be the same as the question before an Inquiry Committee under the Canadian Judicial Council (misconduct) so that a negative answer to the former would not necessarily lead to a negative answer to the latter.

\section{On the Obligation to Give Adequate REASONS IN THE CIVIL CONTEXT}

Perhaps one the most surprising comments in the Cojocaru decision is that it is still an open question whether judges in civil cases have an obligation to provide adequate reasons at all. As mentioned above, in the criminal context, Sheppard ${ }^{144}$ is quite clear that reasons are required and can be set aside if they do not fulfill the basic functions of (1) justifying and

Mysteriously, there are a few references to independence without the accompanying reference to impartiality: see ibid at paras 51, 70, 72, 74-75.

[1985] 2 SCR 673 at 685.

Supra note 18 at para 48 .

This view seems to be shared by Richmond, supra note 111 at 1094, 1096.

Supra note 21. 
explaining the result, (2) telling the losing party why he or she lost, (3) providing public accountability, and (4) permitting effective appellate review. ${ }^{145}$ As Justice Charron put it succinctly, the reasons must show the "why" of the decision. ${ }^{146}$ According to the Court in Cojocaru, "[t]his Court has not explored whether, and if so how, this approach applies in civil cases, although it has twice considered and rejected the argument that reasons were functionally insufficient." 147 The two cases in question there are: (1) in the civil context; where (2) a party was alleging that the reasons of the trial judge were inadequate and should therefore be rejected; (3) the Court cited Sheppard and the requirements that it sets out; (4) the Court carried out a Sheppard analysis; and, (5) the Court concluded that the reasons were not functionally insufficient. ${ }^{148}$ In light of this, one could certainly not be blamed for assuming that Sheppard therefore applied in the civil context. Granted, the Court did not explicitly state that Sheppard did, in fact, apply in the civil context in those two cases, but the issue was squarely before it and the Court dealt with the issue following a Sheppard analysis. Why would the Court bother with the inadequacy argument and Sheppard analysis in those two cases if reasons in civil matters do not have to be adequate in the first place?

Clearly, the majority of the Court of Appeal in Cojocaru thought that Sheppard applied to civil cases, as it found that the reasons of the trial judge did not meet the functional requirement of public accountability, and did not allow for meaningful appellate review. That the Sheppard adequacy requirements apply in the civil context is also the view of the Ontario Court of Appeal. ${ }^{149}$ Various commentators have also concluded that the Sheppard analysis applies to civil cases. ${ }^{150}$ In fact, Chief Justice McLachlin herself wrote the following in an article dealing with the general concept of judicial accountability:

There is also the common practice of giving reasoned, well-written judgments that are publicly reported or otherwise available for public scrutiny. In R. v. Sheppard, Justice Binnie, writing for the Court, noted the general sense in which a duty to give reasons may be said to be owed to the public rather than to the parties to a specific proceeding. These principles are so firmly entrenched in the Canadian judicial system that their significance may go unnoticed. But in the context of judicial accountability, they are of prime importance. ${ }^{151}$

Ibid at para 24. See also REM, supra note 22 at para 11; Walker, supra note 22 at para 19; FH, supra note 22 at para 98; Hamilton, supra note 22.

REM, ibid at para 37.

Supra note 1 at para 25.

FH, supra note 22; Hamilton, supra note 22.

2878852 Canada Inc v Jones Heward Investment Counsel Inc, 2007 ONCA 14, [2007] OJ No 78 (QL) at para 28, citing with approval its earlier decision in Canadian Broadcasting Corp Pension Plan v BF Realty Holdings Ltd (2002), 214 DLR (4th) 121 (Ont CA) at para 64; Barbieri v Mastronardi, 2014 ONCA 416, [2014] OJ No 2419 (QL).

150 William Shores \& David Jardine, "Theirs to Reason Why: A Synopsis of the Administrative Law Jurisprudence Relating to Reasons" (2012) 25:3 Can J Admin L \& Prac 253 at 263: “A common law duty to provide reasons has now also been recognized in the civil and criminal courts. The Supreme Court explained the scope of the duty the civil and criminal law context as an obligation [to fulfill the four basic functions enumerated previously]"; The Honourable Justice Lynn Smith, "The Ring of Truth, the Clang of Lies: Assessing Credibility in the Courtroom" (2012) 63 UNB LJ 10 at 31: "The duty to give reasons applies in civil cases as well" [footnote omitted]; The Honourable John M Evans, "Writing Effective Tribunal Decisions and Reasons" (2002) 16 Can J Admin L \& Prac 95 (WeslawNext Canada): "Sheppard was a criminal case, but I see nothing in the reasons precluding its application to civil litigation as well." See also Factum of the CBA, supra note 115 at para 5: "This approach [Sheppard functional analysis] has been applied to both criminal and civil cases."

151 Rt Hon Beverley McLachlin CJ, "Courts and Judges in the Framework of Accountability - Judicial Accountability” (2008) $1 \mathrm{~J}$ Parliamentary \& Pol L 293 [footnote omitted]. 
There was no mention that judicial accountability is an important element within the realm of criminal law, but not outside of it, because surely that is not the case. In Sheppard, Justice Binnie had linked the giving of reasons to both accountability and legitimacy:

\begin{abstract}
At the broadest level of accountability, the giving of reasoned judgments is central to the legitimacy of judicial institutions in the eyes of the public. Decisions on individual cases are neither submitted to nor blessed at the ballot box. The courts attract public support or criticism at least in part by the quality of their reasons. If unexpressed, the judged are prevented from judging the judges. ${ }^{152}$
\end{abstract}

In my view, the rationale for the giving of adequate reasons expressed by Justice Binnie in Sheppard is applicable in the civil as well as the criminal context. This has been more formally recognized elsewhere. ${ }^{153}$ It is time that it be so in Canada as well — particularly since many clearly thought that it already was. ${ }^{154}$

\title{
XI. Conclusion
}

The Cojocaru decision is one that can easily attract criticism of the "judges can copy, but nobody else can" variety. ${ }^{155}$ The decision is justifiable, however, once one has fully considered the true role of judges and reasons and the realities of the judicial system. The decision will likely bring a sigh of relief to busy judges. It may also encourage lawyers to write better submissions. That said, the fact that the Supreme Court noted that copying is not ideal and is not a practice that should be encouraged raises questions about the workload of judges. Since everyone seems to agree that judges are busy, one can reasonably ask: are they too busy? Are lower standards of judicial writing and reasoning being reluctantly accepted because there are too few judges or judicial resources are too scarce? If increased attention is being put on the adequacy of reasons in the criminal and, arguably, civil contexts, is the workload of judges increasing further as well and is the judiciary fully equipped to handle it? In the end, though reasonable concessions can be made in order to respond to the pressures faced by judges, maintaining public confidence in the administration of justice requires that such concessions be limited.

Sheppard, supra note 21 at para 5.

See e.g. Emery, supra note 39, a case decided in the civil context where the English Court of Appeal held that "justice will not be done if it is not apparent to the parties why one has won and the other has lost" at para 16, and that "if the appellate process is to work satisfactorily, the judgment must enable the appellate court to understand why the Judge reached his decision” at para 19. Note that this is the same case that was, in this author's view, cited erroneously by the Supreme Court in Cojocaru. See footnote 39.

In the specific context of the Cojocaru decision, there was, in this author's view, an inadequacy argument to be addressed (as found by the Court of Appeal and as pleaded by the defendants). Though it perhaps would not have been a winning argument, the Supreme Court should have looked at it, which would have forced it — one would hope — to rule on the question of necessity of adequate reasons in the civil context.

See e.g. Ian Mulgrew, "Supreme Court OK with B.C. Judge Who Copied One Side’s Submissions in Ruling,” Vancouver Sun (24 May 2013), online: <www.vancouversun.com/health/Supreme+Court+with +judge+copies+side+sumission+ruling/8430439/story.html>. 